\title{
SINERGITAS PERAN TRI PUSAT PENDIDIKAN DALAM PEMBELAJARAN BERBASIS DARING DI MASA PANDEMI COVID-19
}

\author{
Sukarman \\ Prodi Pendidikan Agama Islam, Fakultas Tarbiyah dan Ilmu Keguruan \\ Universitas Islam Nahdlatul Ulama Jepara \\ pakar@unisnu.ac.id
}

\begin{abstract}
Abstrak
Tulisan ini dilatarbelakangi oleh adanya pergeseran paradigma pembelajaran berbasis luring pada pembelajaran berbasis daring di masa pandemic Covid-19. Hal tersebut merupakan dampak dari adanya upaya pencegahan dan memutus rantai penyebaran wabah Covid-19 dengan melakukan pembatasan sosial yang berdampak pada banyak aspek kehidupan termasuk pendidikan. Tujuan dari penelitian penelitian ini adalah untuk menganalisa bagaimana problematika, kelebihan, kekurangan, dan kendala dari pelaksanaan pembelajaran berbasis daring di masa pandemic Covid-19 di MI Miftahul Huda Jepara. Temuan dari penelitian ini adalah pembelajaran berbasis daring sangat membantu proses belajar mengajar di masa pandemic Covid-19. Namun pembelajaran berbasis daring juga memunculkan persoalan baru yang kompleks bagi guru, orang tua, dan peserta didik.
\end{abstract}

Kata kunci: pembelajaran daring, pusat pendidikan, Covid-19

\begin{abstract}
Background of this paper is changes on paradigm offline-based learning to online-based learning during pandemic Covid-19. This is the impact of efforts to prevent and cut off the chain of Covid-19 spread by carrying social distancing that have an impact on many aspects in life including education. The purpose of this research study is to analyze how the problems, strengths, weaknesses, and constraints of implementing online-based learning during pandemic Covid-19 at MI Miftahul Huda Jepara. The findings of this study are that online-based learning has greatly helped the teaching and learning process during pandemic Covid-19. However, online-based learning also raises new, complex problems for teachers, parents, and students.
\end{abstract}

Keywords: online learning, education center, Covid-19 


\section{A. PENDAHULUAN}

Pendidikan adalah sebuah proses usaha untuk mendewasakan manusia dan mengarahkan kepada fitahnya. ${ }^{1}$ Pendidikan dalam perspektif pendidikan Islam sejatinya memiliki pengertian dan tujuan yang beragam. ${ }^{2}$ Praktik pendidikan tidak sekedar bersifat kognitif intelektualistik, namun perlu direvitalisasi sebagai wahana pengembangan pendidikan karakter bangsa, pembangunan kecerdasan, akhlak dan kepribadian peserta didik secara utuh sesuai dengan tujuan pendidikan nasional. ${ }^{3}$ Dengan kata lain pendidikan bertujuan membentuk manusia yang mandiri cakap dan terampil dari aspek kognitif, afektif, dan psikomotoriknya. ${ }^{4}$

Pendidikan dalam pandangan Islam bertujuan mengarahkan fitrah manusia sesuai kodratnya. ${ }^{5}$ Aly menyatakan bahwa tujuan pendidikan Islam dapat diklasifikasikan menjadi tiga tujuan pokok, yaitu keagamaan, keduniaan dan ilmu untuk ilmu. Tiga tujuan tersebut terintegrasi dalam satu tujuan yang disebut tujuan tertinggi pendidikan Islam, yaitu tercapainya insan kamil. ${ }^{6}$ Berdasarkan pengertian dan tujuan pendidikan di atas tampak bahwa penekanan pendidikan Islam adalah pada "bimbingan" yang menyangkut ranah iman, ilmu, amal, akhlak dan sosial. Dengan demikian pendidikan Islam tidak hanya menyangkut hubungan makhluk dengan Khalik-nya saja, akan tetapi juga hubungan makhluk dengan makhluk lain. Tidak hanya menyangkut hablun min-Allah akan tetapi juga hablun min al-nas. ${ }^{7}$ Adapun tujuan akhir pendidikan

${ }^{1}$ Ahmad Tafsir, Ilmu Pendidikan Dalam Perspektif Islam, ed. Tjun Surjaman, 11th ed, Bandung: PT Remaja Rosdakarya, 2014. Tafsir menyatakan tujuan pendidikan Islam beragam sesuai term yang digunakan. Pendidikan dalam perspektif Islam menurut Tafsir memiliki beberapa term yaitu; Tarbiyah, Ta'dib dan Ta'lim. yang ketiganya memiliki pengertian yang spesifik meskipun semua istilah tersebut sering digunakan untuk menyebut pendidikan Islam.

2 Abuddin Nata, Ilmu Pendidikan Islam, 2nd ed, Jakarta: Kencana, 2012.Nata meyebutkan setidaknya ada 13 istilah yang umum digunakan dalam pendidikan Islam, yaitu; tarbiyah, ta'lim, ta'dib, tahdzib, mauodzah, Riyadloh, Tazkiyah, talqin, tadris, tafaqquh, tabyin, tazkirah, irsyad. Implikasinya adalah tujuan pendidikan Islam beragam sesuai dengan pengertian dari setiap istilah yang digunakan.

${ }^{3}$ Darul Ilmi, Pendidikan Karakter Berbasis Nilai-Nilai Kearifan Lokal Melalui Ungkapan Bijak Minangkabau, ISLAM REALITAS: Journal of Islamic \& Social Studies 1, no. 1, 2015, hlm.48.

${ }^{4}$ Abu Ahmadi and Nur Uhbiyati, Ilmu Pendidikan, Jakarta: Rineka Cipta, 2015.

5 Kristi Wardani, PERAN GURU DALAM PENDIDIKAN KARAKTER KI HADJAR DEWANTARA, in Proceedings of The 4th International Conference on Teacher Education; Join Conference UPI \& UPSI Bandung, Indonesia, 8-10 November 2010, Bandung: UPI \& UPSI Bandung, 2010, hlm. 8-10.

${ }^{6}$ Aas Siti Sholikhah, Teori-Teori Pendidikan, Jurnal Edukasi Islami Jurnal Pendidikan Islam 7, no. 1,2018

${ }^{7}$ Arifin, ILMU PENDIDIKAN ISLAM; Tinjauan Teoritis Dan Praktis Berdasarkan Pendekatan Interdisipliner, Jakarta: Pustaka Setia, 2014. 
Islam adalah terwujudnya ketundukan yang sempurna kepada Allah, baik secara pribadi, komunitas, maupun seluruh umat manusia. ${ }^{8}$

Tujuan Pendidikan akan tercapai dengan proses pembelajaran. Proses Belajar Mengajar (PBM) dapat berlangsung karena terpenuhinya komponen- komponen pendidikan $^{9}$ salah satunya adalah adanya interaksi edukatif antara dua pihak yakni pendidik dan peserta didik, dalam arti Proses Belajar Mengajar (PBM) terjadi karena terpenuhinya unsur-unsur pendidikan berupa interaksi edukatif terdiri atas aksi dan reaksi dengan kata lain pendidikan melibatkan unsur stimulus dan respon. Secara garis besar, komponen-komponen yang termuat dalam sistem pendidikan Islam sekarang ini merupakan pengembangan dari sistem pendidikan terdahulu. Ditinjau dari perspektif sejarah, sistem pendidikan Islam yang pertama kali terdiri dari dua komponen, yaitu tujuan dan alat pendidikan. Kemudian mengalami perkembangan sehingga komponen sistem pendidikan Islam itu terdiri atas tujuan, pendidik, anak didik, sarana/alat dan lingkungan. ${ }^{10}$

Pendidikan mengalami problematika baru dengan munculnya wabah/pandemi Covid-19 yang menjadi isu global di seluruh negara di dunia dan berdampak pada seluruh aspek kehidupan. Penyebarannya yang secara cepat dan massif telah melumpuhkan sendi kehidupan ekonomi, sosial keagamaan, tidak terkecuali pendidikan. Hal ini memaksa untuk tidak menerapkan alternatif dalam Proses Belajar Mengajar (PBM) sebagai pengganti pertemuan tatap muka mengingat virus ini menular dari manusia ke manusia. Jika dilihat dari gejalanya, orang awam akan mengiranya hanya sebatas influenza biasa, tetapi bagi analisis kedokteran virus ini cukup berbahaya dan mematikan. Saat ini di tahun 2020, perkembangan penularan virus ini cukup signifikan karena penyebarannya sudah mendunia dan seluruh negara merasakan dampaknya termasuk Indonesia. Upaya untuk mengantisipasi dan mengurangi jumlah penderita virus corona di Indonesia sudah dilakukan di seluruh daerah. Diantaranya dengan memberikan kebijakan membatasi aktifitas keluar rumah, kegiatan sekolah dirumahkan, bekerja dari rumah (work from home), bahkan kegiatan beribadah pun dirumahkan. Hal

\footnotetext{
${ }^{8}$ Kamrani Buseri, Dasar, Asas, Dan Prinsip Pendidikan Islam, ed. Ahmad Juhaidi, 1st ed, Yogyakarta: Aswaja Pressindo, 2014.

9 Khoirul Huda, Problematika Madrasah Dalam Meningkatkan Mutu Pendidikan Islam, Dinamika Penelitian 16, no. 2 (2016): 336.hlm 8.

10 Sitti Nadirah, Anak Didik Perspektif Nativisme, Empirisme, Dan Konvergensi, Lentera Pendidikan: Jurnal Ilmu Tarbiyah Dan Keguruan 16, no. 2, 2013, hlm.188-195.
} 
ini sudah menjadi kebijakan pemerintah berdasarkan pertimbangan-pertimbangan yang sudah dianalisa dengan maksimal tentunya. ${ }^{11}$

Berdasarkan latar belakang tersebut tulisan ini akan mengulas dan menganalisa menganalisa bagaimana pelaksanaan pembelajaran berbasis daring di masa pandemi Covid-19, kelebihan, kekurangannya dan problematikanya di MI Miftahul Huda Jepara. Fokus penelitian berkaitan dengan peran tripusat pendidikan dalam pembelajaran berbasis daring di masa pandemi Covid-19, dampak pembelajaran daring bagi anak, problematika dan alternatif solusinya supaya tujuan dan esensi pendidikan tetap dapat tercapai melalui Proses Belajar Mengajar (PBM).

\section{B. METODE PENELITIAN}

Penelitian ini merupakan sebuah penelitian studi kasus (case study) ${ }^{12}$ di lapangan (field research $)^{13}$ bersifat deskriptif dengan pendekatan kualitatif. Penelitian ini menyoroti pelaksanaan pembelajaran berbasis daring di masa pandemi Covid 19 sejak bulan Maret sampai dengan Juni 2020 dilakukan di MI Miftahul Huda Kedung Jepara. Penggalian data Penelitian ini dilakukan dengan beberapa teknik yakni observasi non partisipan, ${ }^{14}$ wawancara dengan stake holder, dan dokumentasi karena hasil penelitian dari observasi dan wawancara akan menjadi lebih terpercaya (kredibel) jika didukung oleh dokumentasi. ${ }^{15}$

${ }^{11}$ Hasbullah, Dasar-Dasar Ilmu Pendidikan, 11th ed., Jakarta: PT Raja Grafindo Persada, 2013.

${ }^{12}$ W Lawrence Neuman, Social Research Methods: Qualitative and Quantitative Approaches, 7th ed., United States of America: Pearson Education Limited, 2014. Mendiskripsikan studi kasus “... a comprehensive study of a social unit be that unit a person, a group, a social institution, a district or a community."... Studi kasus adalah salah satu studi komprehensif dari sebuah unit sosial baik itu perseorangan, sebuah kelompok, insytitusi atau lembaga sosial, distrik ataupun masyarakat.

${ }^{13}$ Directorate of Distance Education, Research Methodology, New Delhi: EXCEL BOOKS PRIVATE LIMITED, 2012.hlm. 433. Banyak orang menikmati penelitian lapangan karena itu melibatkan "bergaul" dengan orang-orang. Tidak memiliki matematika dingin atau statistik rumit dan tidak ada hipotesis deduktif abstrak. Sebaliknya, dalam melibatkan interaksi sosial langsung dan tatap muka dengan "orang sungguhan" dalam lingkungan sosial yang alami. Penelitian lapangan menarik bagi mereka yang menyukai orang-orang yang menonton. Laporan penelitian lapangan dapat menarik, mengungkap rekening dunia sosial yang tidak dikenal. Beberapa studi lapangan sama menariknya untuk dibaca sebagai karya fiksi dengan keasyikan film thriller atau misteri.

${ }^{14}$ Sugiyono, Metode Penelitian Kuantitatif, Kualitatif Dan R\&D, 26th ed. Bandung: Alfabeta, 2017.hlm. 227. Observasi partisipatif maksudnya peneliti terlibat dengan kegiatan sehari hari orang yang sedang diamati atau orang yang sedang dijadikan sebagai sumber data penelitian. Sedangkan partisispasi pasif (non partisipatif) artinya peneliti datang ke tempat kegiatan orang yang diamati (informan) tetapi tidak terlibat dalam kegiatan yang dilakukan oleh informan.

15 W Lawrence Neuman, Social Research Methods: Qualitative and Quantitative Approaches, England: Pearson Education Limited, 2014.hlm 240. Bogdan sebagaimana dikutip oleh Sugiyono mengatakan "in most tradition of qualitative reseach, the phrase personal document is used broadly to refers to any first person produced by an individual which describes his or his own actions, experience and belief". 


\section{HASIL DAN PEMBAHASAN}

Tri pusat pendidikan adalah konsep yang dipopulerkan oleh seorang maestro pendidikan nasional yakni Ki Hajar Dewantara. Dimana terdapat 3 lembaga atau lingkungan pendidikan yang terdiri atas keluarga, sekolah, dan masyarakat. ${ }^{16}$ Kurniawan mendefinisikan Tri pusat pendidikan merupakan tiga pusat yang memiliki tanggung jawab atas terselenggaranya pendidikan terhadap anak, tiga pusat tersebut yaitu pendidikan dalam keluarga, dalam sekolah dan dalam masyarakat. Tiga lingkungan pendidikan tersebut merupakan sarana yang tepat dalam pendidikan dan pembentukan karakter, perlu adanya kerjasama dari berbagai lingkungan pendidikan, baik pendidikan dalam keluarga, pendidikan dalam sekolah, dan pendidikan dalam masyarakat. Dengan adanya kerjasama antara pendidikan dalam keluarga, pendidikan dalam sekolah dan pendidikan dalam masyarakat akan dapat menanamkan pengetahuan (transfer of knowledge) dan nilai-nilai (transfer of values) dengan baik sehingga dapat membentuk pribadi anak menjadi insan kamil. ${ }^{17}$

Sementara dalam pendidikan Islam sebagaimana diusung oleh salah satu tokoh pemikir dalam pendidikan Islam Abdurrahman An-Nahlawi dalam kitabnya yang berjudul "Ushulut Tarbiyah Islamiyah wa Asalibiha fil Baiti wal Madrasati wal Mujtama'" atau dalam versi Bahasa Indonesia berjudul "Pendidikan Islam di Rumah, Sekolah, dan Masyarakat" konsep Tri pusat pendidikan Dalam karya tersebut AnNahlawi menyatakan bahwa pendidikan dalam Islam terdapat tiga lembaga penting yang menjadi pusat pendidikan. ${ }^{18}$

Pembelajaran berbasis daring bukanlah sesuatu yang asing. Istilah "daring" sendiri merupakan akronim dalam bahasa Indonesia yakni "dalam jaringan” yang merupakan terjemahan dari bahasa Inggris "online". Kata daring merupakan lawan kata dari "luring" (luar jaringan) yang merupakan terjemahan dari bahasa Inggris "offline". Dengan demikian dapat dipahami bahwa pembelajaran berbasis daring adalah pembelajaran yang dilakukan yang dilakukan dengan menggunakan media perantara berupa jaringan internet.

${ }^{16}$ Machful Indra Kurniawan, Tri Pusat Pendidikan Sebagai Sarana Pendidikan Karakter Anak Sekolah Dasar, JOURNAL PEDAGOGIA 4, no. 1, 2015, hlm.41-49.

${ }^{17}$ Ramayulis, Ilmu Pendidikan Islam, 10th ed, Jakarta: Kalam Mulia, 2013.

${ }_{18}$ Machful Indra Kurniawan, Tri Pusat Pendidikan Sebagai Sarana Pendidikan Karakter Anak Sekolah Dasar, PEDAGOGIA: Jurnal Pendidikan 4, no. 1, 2015: 41-49. hlm. 139. 
Istilah model pembelajaran daring atau Online Learning Models (OLM), pada awalnya digunakan untuk menggambarkan sistem belajar yang memanfaatkan teknologi internet berbasis komputer (computer-based learning/CBL). Dalam perkembangan selanjutnya, fungsi komputer telah digantikan oleh telepon seluler atau gawai. Pembelajaran dapat berlangsung lebih luwes dibandingkan jika menggunakan komputer. Orang dapat belajar di manapun, kapanpun, dan dalam situasi apapun. ${ }^{19}$

Melalui pembelajaran virtual atau pembelajaran daring, pembelajaran tidak terbatas oleh ruang dan waktu. Interaksi antara guru dan siswa berlangsung kapanpun dan dimanapun. Pembelajaran daring menjadi keuntungan tersendiri bagi guru dan siswa yang dapat menjadikan siswa semakin aktif dalam mengonstruk ilmu pengetahuan. Pembelajaaran daring dapat dijadikan solusi pembelajaran jarak jauh ketika terjadi bencana alam. ${ }^{20}$ Meski demikian ada konsekwensi yang harus dipenuhi yakni media pembelajaran sebagai pendukung berlangsungnya pembelajaran daring.

Covid-19 atau Coronavirus merupakan sekumpulan virus dari subfamili Orthocronavirinae dalam keluarga Coronaviridae dan ordo Nidovirales. Kelompok virus ini yang dapat menyebabkan penyakit pada mamalia dan burung, termasuk manusia. Coronavirus menyebabkan infeksi saluran pernapasan pada manusia yang umumnya ringan, seperti pilek, meskipun beberapa bentuk penyakit seperti; MERS, SARS, dan COVID-19 sifatnya lebih mematikan. Jika dilihat dari gejalanya, orang awam akan mengiranya hanyalah sebatas influenza biasa, tetapi bagi analisis kedokteran virus ini cukup berbahaya dan mematikan. Coronavirus bermula dari Wuhan Tiongkok sejak 2019. Di tahun 2020 perkembangan dan penularan virus ini sangat signifikan karena penyebarannya sudah mendunia dan seluruh negara merasakan dampaknya termasuk Indonesia.

Upaya mengantisipasi dan memutus rantai penyebarannya untuk mengurangi jumlah penderita Covid-19 di Indonesia relah diberlakukan di seluruh daerah. Diantaranya adalah dengan memberikan kebijakan pembatasan aktifitas keluar rumah, kegiatan sekolah dirumahkan/school from home (SFH), bekerja dari rumah/work from

${ }^{19}$ Nurul Lailatul Khusniyah and Lukman Hakim, Efektivitas Pembelajaran Berbasis Daring: Sebuah Bukti Pada Pembelajaran Bahasa Inggris, Jurnal Tatsqif 17, no. 1 (2019): 19-33, doi:10.20414/jtq.v17i1.667.

${ }^{20}$ Hikmah Uswatun Ummi and Indrya Mulyaningsih, Journal Indonesian Language Education and Literature, Journal Indonesian Language Education and Literature 3, no. 1 (2017): 53-65, http://www.syekhnurjati.ac.id/jurnal/index.php/jeill/\%0APEMBELAJARAN. 
home (WFH), bahkan kegiatan beribadah pun dirumahkan. Hal ini sudah menjadi kebijakan pemerintah berdasarkan kajian, pertimbangan-pertimbangan yang sudah dianalisa dengan maksimal tentunya. ${ }^{21}$ Akibat Pandemi ini, pemerintah Indonesia mengeluarkan kebijakan sebagai upaya lanjut untuk membatasi ruang gerak penularan Covid 19 dengan berbagai cara, termasuk melakukan Pembatasan Sosial Berskala Besar (PSBB). PSBB adalah kebijakan berupa pembatasan ruang gerak masyarakat untuk melakukan aktifitasnya di luar rumah demi upaya social distancing/ physical distancing. ${ }^{22}$

Praktik pembelajaran berbasis daring banyak sekali ragam media dengan berbagai macam platform melalui telepon genggam misalnya WhatsApp, Facebook, google classroom, Elearning, dan web blog lain sebagainya. Hasil penelitian menunjukan bahwa siswa yang banyak berinteraksi dengan aplikasi di telepon genggam dapat lebih mudah memahami isi teks bacaan. ${ }^{23}$ Pembelajaran daring di MI Mifathul Huda menggunakan media sosial grup WhatsApp yang dibuat oleh guru. Bentuk materi yang diberikan berupa video, teks dalam format pdf yang dibagikan oleh guru sebagai admin grup WhatsApp, kemudian diterima oleh wali siswa untuk dipelajari oleh anak mereka masing-masing. Dalam pembelajaran tersebut disertai pula penugasan yang harus dikerjakan oleh siswa. Setelah dikerjakan kemudian tugas tersebut dikirimkan kembali kepada guru untuk dilakukan koreksi dan penilaian hasil belajar siswa.

Pembelajaran berbasis daring di MI Miftahul Huda Jepara memiliki sejumlah kendala dalam pelaksanaanya. Hal tersebut dapat ditilik dari beberapa segi. Adapun problematika tersebut antara lain sebagai berikut:

Pertama, pembelajaran daring bagi anak SD/MI tidak bisa dilepas begitu saja dengan kata lain belajar mandiri. Mereka perlu pendampingan dari orang tua. Hal ini cukup beralasan karena dampak dari penggunaan gawai bisa berdampak negatif bagi

${ }^{21}$ Albitar Septian Syarifudin, Impelementasi Pembelajaran Daring Untuk Meningkatkan Mutu Pendidikan Sebagai Dampak Diterapkannya Social Distancing, Jurnal Pendidikan Bahasa Dan Sastra Indonesia Metalingua 5, no. 1 (2020): 31-34, doi:10.21107/metalingua.v5i1.7072. SALAM: Jurnal Sosial dan Budaya Syar-I, 7, no.3, 2020, hlm. 227 - 238.

${ }^{22}$ Nur Rohim Yunus and Annissa Rezki, Kebijakan Pemberlakuan Lockdown Sebagai Antisipasi Penyebaran Corona Virus Covid-19, SALAM; Jurnal Sosial \& Budaya Syar-I 7, no. 3, 2020, hlm. 22738, doi:10.15408/sjsbs.v7i3.15083.

${ }^{23}$ Indra Rahmatullah, Jaminan Hak Kesehatan Pekerja Work From Office Selama Masa PSBB Covid-19, Jurnal Buletin Hukum Dan Keadilan 4, no. 1, 2020, hlm.57-62. 
kesehatan yaitu menurunnya ketajaman penglihatan. ${ }^{24}$ Permasalahannya adalah kondisi wali siswa tidak seluruhnya melek teknologi (gaptek). Sebagian wali siswa mengalami kesulitan ketika mendampingi anak dalam pembelajaran daring. Bagaimana tidak, jangankan mengoperasikan telepon pintar, di lapangan masih dijumpai sebagian wali siswa tidak dapat mengoperasikan telepon genggam meskipun sekedar mengirim dan menerima pesan singkat ataupun membuat dan menelrima panggilan telepon. Hal ini sesuai dengan pendapat Slameto yang menyatakan bahwa selama pembelajaran di rumah, diperlukan kemampuan menggunakan komputer atau hp dan internet, di mana belum dikuasai oleh banyak anak, termasuk juga orang tua, dan guru. Apalagi di beberapa tempat $34 \%$ guru masih mengeluh terkait dengan kualitas jaringan internetnya. $^{25}$

Kedua, minimnya waktu orang tua dalam melakukan pendampingan terdahadap anak saat belajar. Mayoritas wali siswa adalah pekerja pabrik dengan durasi waktu kerja bersamaan dengan durasi anak belajar. Sebelum masa pandemi covid-19 anak belajar di sekolah pukul 07.00 pagi sampai dengan pukul 13.00 di sekolah dengan pendampingan dari guru kelas. Ketika masa pandemic covid-19 anak belajar di rumah tanpa pendampingan oleh guru. Fungsi pendampingan belajar dilakukan oleh orang tua sebagai perantara atas materi dan penugasan dari guru kepada siswa sekaligus operator media pembelajaran. Sementara itu orang tua berada pada posisi sedang bekerja di pabrik. Kalaupun ketika berada di rumah adalah malam hari. Hal ini menjadi lebih susah ketika pabrik mengharuskan lembur atau ketika harus berganti shift malam.

Seyogyanya, dibutuhkan peran orang tua sebagai pengganti guru di rumah dalam mendampingi dan membimbing anaknya selama proses Pembelajaran Jarak Jauh (PJJ). Menurut Winingsih paling tidak terdapat empat peran orang tua selama Pembelajaran Jarak Jauh (PJJ) yaitu: pertama, orang tua memiliki peran sebagai guru di rumah, yang di mana orang tua dapat membimbing anaknya dalam belajar secara jarak jauh dari rumah. Kedua, orang tua sebagai pengarah atau direktor. Ketiga, orang tua berperan sebagai fasilitator, yaitu orang tua sebagai sarana dan pra-sarana bagi anaknya dalam

${ }^{24}$ Widea Ernawati, Pengaruh Penggunaan Gadget Terhadap Penurunan Tajam Penglihatan Pada Anak Usia Sekolah (6-12 Tahun) Di SD Muhammadiyah 2 Pontianak Selatan.”. 5-6., Jurnal Keperawatan Muhammadiyah 3, no. 1, 2018.

25 Slameto, 5 Fakta Pendidikan Di Tengah Wabah Corona.," Detiknews Website, 2020, https://news.detik.com/kolom/d-4969335/5- faktapendidikan-di-tengah-wabah-corona. 
menjalankan pembelajaran jarak jauh. Keempat, orang tua sebagai motivator, yakni orang tua harus memberikan dorongan semangat serta dukungan kepada anaknya dalam melaksanakan pembelajaran dari rumah, sehingga anak memiliki semangat untuk belajar, serta memperoleh prestasi yang baik. ${ }^{26}$

Ketiga, ketidaksabaran orang tua dalam mendampingi anak saat belajar menjadi persoalan lain dalam pembelajaran berbasis daring di masa pandemi. Hal ini disebabkan oleh beberapa faktor yaitu; orang tua sudah terbiasa menyerahkan pembelajaran anak di tangan guru dengan kata lain porsi guru lebih besar daripada orang tua. Ketika di masa pandemi porsi pendampingan belajar terhadap anak berbalik. Porsi orang tua lebih besar disbanding guru mengingat pembelajaran berlangsung dari rumah atau School from Home (SFH). Faktor lain yang juga menyumbang problematika adalah tidak semua orang tua memiliki intelektualitas yang mumpuni untuk mendampingi anak belajar.

Keempat, media komunikasi sebagai sarana pembelajaran daring juga menyumbang kendala dalam pembelajaran berbasis daring di masa pandemi. Bagaimana tidak, meskipun telepon genggam berupa smart phone adalah sesuatu yang biasa di era sekarang, namun bagi sebagian orang telepon genggam masih menjadi benda istimewa. Meskipun media pembelajaran ini cenderung sederhana artinya tidak menggunakan computer, laptop dan media lainnya faktanya masih juga dijumpai kendala dalam media pembelajaran. Cahyati menyatakan bahwa meskipun guru dan pendidik telah berusaha menyikapi pembelajaran jarak jauh dengan memberikan tugas pelajaran melalui daring. Namun hal ini tidak selalu berjalan baik, dalam pelaksanaannya dijumpai banyak kendala misalnya kuota dan signal yang buruk/tidak memadai, beberapa peserta didik tidak memiliki smart phone sehingga peserta didik mengalami kesulitan belajar. ${ }^{27}$

Kelima, pengeluaran biaya lebih besar. Pembelajaran jarak jauh (PJJ) atau belajar dari rumahdi MI Miftahul Huda berdampak pada pengeluaran yang lebih besar, yaitu paket data internet dan pulsa. Pada sebagian peserta didik untuk mengakses pembelajaran daring memerlukan smart phone atau juga laptop ataupun komputer. Pernyataan senada juga diungkapkan oleh Purwanto bahwa kendala yang dihadapi para orangtua adalah adanya penambahan biaya kuota internet. Pembelajarn daring

${ }^{26}$ Endang Winingsih, Peran Orang Tua Dalam Pembelajaran Jarak Jauh., 2020, Poskita.co, 2020, https://poskita.co/2020/04/02/peran-orangtua- dalampembelajaran-jarak-jauh/\%0AWHO.

27 Nika Cahyati and Rita Kusumah, Peran Orang Tua Dalam Menerapkan Pembelajaran Di Rumah Saat Pandemi Covid 19, Jurnal Golden Age 4, no. 1, 2020, hlm152-59. 
membutuhkan koneksi internet. Semakin baik koneksi dibutuhkan biaya yang makin besar. Materi pelajaran tertentu juga membutuhkan jumlah paket data yang lebih tergantung pada jenis aplikasi pembelajaran dan besarnya ukuran file pelajaran yang dibagikan kepada peserta didik. ${ }^{28}$

Meskipun anak-anak era milenial jaman sekarang akrab dengan gawai, pembelajaran daring bagi anak tidak bisa dilepas begitu saja tanpa ada pendampingan dari orang tua. Mengingat fungsi gawai selain sebagai media informasi dan media edukasi, gawai juga menjadi media rekreasi (hiburan). Harfiyanto menyatakan bahwa gawai bukan hanya sekedar alat yang menyajikan aplikasi jejaring sosial namun juga media informasi berita dan hiburan bagi penggunanya. ${ }^{29}$ Kecanduan gawai adalah hal yang perlu diwaspadai oleh para orang tua. Tanpa pengawasan fungsi gawai tidak lagi proporsional antara ketiga fungsi tersebut. Tanpa pendampingan orang tua, anak bisa saja lebih besar porsinya dalam permainan daripada pendidikan. Anak belum sepenuhnya memahami dampak positif dan negatif penggunaan gawai. Terlebih saat ini banyak orangtua memberikan gawai kepada anaknya dan mereka juga memberi kebebasan dalam mengunakan gawai. Menurut Ernawati penggunaan gawai pada anak saat usia sekolah dianggap terlalu dini. ${ }^{30}$

Perubahan pola pembelajaran di sekolah pada pembelajaran di rumah atau dikenal dengan pembelajaran jarak jauh (PJJ) membutuhkan adaptasi tersendiri bagi anak. Semula pembelajaran terkondisikan secara klasikal di sekolah, ketika harus belajar dari rumah tanpa bertemu muka dengan teman dan guru secara fisik menjadikan suasana atmosfer yang berbeda bagi anak. Masa pandemi yang tak kunjung usai dengan konsekwensi pembelajaran jarak jauh terus menerus membuat anak jenuh. Bahkan

28 Yuli Irmayanti, Peran Orangtua Dalam Mendampingi Penggunaan Gawai Pada Anak Prasekolah, New England Journal of Medicine (Universitas Muhammadiyah Surakarta, 2018,http://www.ncbi.nlm.nih.gov/pubmed/7556065\%0Ahttp://www.pubmedcentral.nih.gov/articlerende r.fcgi?artid=PMC394507\%0Ahttp://dx.doi.org/10.1016/j.humpath.2017.05.005\%0Ahttps://doi.org/10.100 7/s00401-018-1825-z\%0Ahttp://www.ncbi.nlm.nih.gov/pubmed/27157931.

29 Doni Harfiyanto, Cahyo Budi Utomo, and Tjaturahono Budi, Pola Interaksi Siswa Pengguna Gadget Di SMA N 1 Semarang, Journal of Educational Social Studies 4, no. 1, 2015.

${ }^{30}$ Kadek Hengki Primayana and Putu Yulia Angga Dewi, Hubungan Pola Asuh Demokratis Dan Intensitas Penggunaan Gawai Pada Anak Usia Dini, Jurnal Obsesi : Jurnal Pendidikan Anak Usia Dini 5, no. 1, 2020, 710, doi:10.31004/obsesi.v5i1.697. 
pembelajaran dalam beberapa kasus dapat memicu stres tingkat rendah sampai dengan tingkat sedang. ${ }^{31}$

Interaksi edukatif juga dirasa tidak maksimal. Bagaimanapun juga interaksi di dunia nyata dengan dunia maya tentu berbeda. Kegiatan pembelajaran yang dilakukan dengan jarak jauh (PJJ) dengan pembelajaran jarak dekat tentu berbeda. Proses Belajar Mengajar (PBM) berbasis daring di masa pandemi tentu berbeda dengan pembelajaran berbasis luring. Pembelajaran daring lebih sulit memantau peserta didik. Misalnya memantau kesungguhan anak dalam Proses Belajar Mengajar (PBM). Ketika PBM berbasis luring guru dengan mudah memantau, mengawasi, memberikan perhatian dan mengatasi kesulitan belajar peserta didik secara langung (on site).

Proses Belajar Mengajar (PBM) antara guru dan peserta didik di MI Miftahul Huda berbasis daring selain gawai membutuhkan media perantara yakni orangtua. Pembelajaran berbasis daring menjadikan proses transmisi dari guru kepada peserta didik melalui jalur birokrasi yang lebih panjang, dalam arti ketika pembelajaran berbasis luring proses transmisi dari guru kepada peserta didik. Sementara ketika pembelajaran daring proses transmisi harus melawati dari guru kepada peserta didik melewati pihak perantara yakni orangtua sehingga proses transmisi lebih lama.

Pembelajaran berbasis daring untuk menyikapi Proses Belajar Mengajar (PBM) di masa pandemi bisa dikatakan sebagai alternatif solusi yang dianggap paling tepat. Bagaimana tidak, masa pandemi covid 19 di mana semua orang harus menjaga jarak fisik dan jarak sosial dengan melakukan physical distancing dan social distancing kegiatan pendidikan PBM harus tetap berjalan. Hal ini di maksudkan bahwa kegiatan pembelajaran harus tetap berjalan dan tidak boleh berhenti. ${ }^{32}$ Meskipun pembelajaran daring menjadi alternatif solusi yang paling sesuai dalam menyikapi adanya namun dalam pelaksanaanya tetap menjumpai permasalahan.

Sebagaimana paparan hasil temuan dalam pelaksanaan pembelajaran berbasis daring di MI Miftahul Huda Jepara diatas perlu penekanan kembali pihak pihak terkait yang memiliki peran dan andil dalam keberhasilan pendidikan. Untuk itu perlu

\footnotetext{
31 Ade Chita Putri Harahap, Dinda Permatasari Harahap, and Samsul Rivai Harahap, Analisis Tingkat Stres Akademik Pada Mahasiswa Selama Pembelajaran Jarak Jauh Dimasa Covid-19, Biblio Couns: Jurnal Kajian Konseling Dan Pendidikan 3, no. 1, 2020.

${ }^{32}$ Arifin, ILMU PENDIDIKAN ISLAM; Tinjauan Teoritis Dan Praktis Berdasarkan Pendekatan Interdisipliner. Menyatakan bahwa pendidikan berlangsung seumur hidup. Dalam Islam dikenal dengan konsep belajar sepanjang hayat (life long education).
} 
dilakukan upaya untuk memaksimalkan peran 3 lembaga pendidikan (tripusat pendidikan).

Pertama, mengedukasi orang tua. Selama ini orang tua memiliki paradigma bahwa tugas mendidik adalah tugas lembaga pendidikan. Dalam hal ini dilakukan oleh guru, ustad, dosen dan sebuatan pendidik sejenis sesuai dengan karakteristiknya. ${ }^{33}$ Namun hal ini tidak sepenuhnya benar. Orang tua/ keluarga adalah lembaga pendidikan pertama dan utama bagi anak. Dengan kata lain pendidik pertama bagi seorang anak adalah orangtua. ${ }^{34}$ Orang tua harusnya tidak melemparkan tanggung jawab mendidik secara sepihak kepada sekolah/guru sebagaimana yang dilakukan oleh kebanyakan orang tua.

Hal ini tentunya sangat beralasan. Bagaimana tidak, jika dibandingkan dari durasi kebersamaan dalam 24 jam sehari peserta didik lebih banyak bersama orang tua dibandingkan interaksi peserta didik dengan guru di sekolah. Dengan demikian porsi orangtua lebih banyak dibandingkan dengan guru.

Rasio perbandingan durasi kebersamaan antara guru dan orang tua bersama anak tersebut diatas acap kali menjadi dalih bagi guru untuk menempatkan posisi amannya yang seolah olah dalam pandangan guru orang tualah yang lebih bertanggung jawab atas pendidikan peserta didik. Terlebih di masa pandemic covid 19 anak lebih banyak bersama orang tua di rumah. Hal tersebut tidak sepatutnya dilakukan oleh guru. Seharusnya guru mencari solusi untuk meningkatkan perannya dalam menjaga kualitas PBM. Meskipun interaksi fisik guru dengan peserta didik berkurang dalam kuantitas namun PBM tidak boleh berkurang secara kualitas.

\section{SIMPULAN}

Secara garis besar pembelajaran berbasis daring bagi peserta didik jenjang Sekolah Dasar/Madrasah Ibtidaiyah sangat membantu, karena menjadi alternatif solusi di masa pandemic covid 19 di mana masyarakat harus melakukan physical distancing

${ }^{33}$ Hasbullah, Dasar-Dasar Ilmu Pendidikan. Menyatakan bahwa pendidik memiliki sebutan sesuai dengan kekhasan karakteristiknya. Misalnya guru adalah sebutan bagi pendidik di sekolah, kiai atau ustad adalah sebutan bagi pendidik di pesantren, dosen adalah sebutan bagi pendidik di perguruan tinggi, instruktur adalah sebutan bagi pendidik dalam lebaga kursus keahlian tertentu.

${ }^{34}$ Hasan Basri and Beni Ahmad Saebani, ILMU PENDIDIKAN ISLAM, Bandung: Pustaka Setia, 2010. Menyatakan bahwa mendidik seorang anak adalah kewajiban orang tua. Pendidikan pertama yang diperkenalkan kepada anak adalah pendidikan ketauhidan dengan mengenalkan sanag anak kepada Tuhannya. Misalnya ketika anak baru saja dilahirkan diperdengarkan dengan kumandang adzan. Setelah pendidikan keluarga, lembaga pendidikan kedua adalah sekolah/madrasah. Dalam hal ini peran pendidikan dipegang oleh guru. Namun bukan berarti orangtua lepas dari tanggung jawabnya. 
dan social distancing untuk mencegah dan memutus mata rantai penyebaran virus. Meskipun demikian tidak ada media pembelajaran yang paling sempurna/terbaik melainkan masing masing media pembelajaran memiliki kelebihan dan kekurangan. Masing masing media memiliki dampak positif dan dampak negatif. Setiap media pembelajaran memuat kelebihan dan kekurangan. Demikian halnya dengan pembelajaran berbasis daring di MI Miftahul Huda Jepara. Diantara kelebihan/ sisi positifnya adalah; Pembelajaran daring menjadi jembatan satu satunya bagi terselenggaranya PBM di tengah pandemic, meskipun sekolah diliburkan peserta didik tetap belajar dengan melakukan kegiatan sekolah dari rumah / School From Home (SFH), para guru tetap melaksanakan tugas dan kewajibannya sebagai pendidik dengan melakukan kerja dari rumah / work from home (WFH), bagi guru pembelajaran daring efisien dari dari beberapa segi misalnya waktu dan tanaga. Guru dapat melakukan pembelajaran dari rumah tanpa harus melakukan mobilitas sebagiamana rutinitas pembelajran berbasis luring yang harus datang ke sekolah setiap pagi dan pulang siang dan sore hari. Guru dapat mengerjakan pekerjaan rumah tanpa harus meninggalkan tugasnya sebagai seorang pendidik. Dengan bekerja dari rumah seorang guru tetap dapat menjalankan perannya sebagai orangtua mengurus dan memantau anak anaknya. Sebagian guru dapat memangkas pengeluaran kebutuhan rumah tangga misalnya jasa pengasuh (baby sitter). Selama pembelajaran luring seorang guru sekaligus orangtua harus meninggalkan anaknya di rumah dersama seorang pengasuh karena tidak memungkinkan bagi guru untuk mengajar dengan membawa anak ke sekolah. Jadi dengan pembelajaran daring guru dengan peran ganda sebagai orang tua dapat memangkas biaya pengasuh. Kelebihan pembelajaran berbasis daring bagi guru lainnya adalah memangkas biaya transportasi. Dalam pembelajaran berbasis luring setiap hari para guru melakukan mobilitas rutin berangkat dari rumah ke sekolah begitu sebaliknya. Ketika pembelajaran berbasis daring guru tidak perlu melakukan mobilitas yang memerlukan anggaran perjalanan.

Pembelajaran daring di MI Miftahul Huda Jepara juga memiliki kekurangan/sisi negatif. Bagi peserta didik dan wali peserta didik, pembelajaran daring dianggap merepotkan karena beberapa hal misalnya peralihan dari pembelajaran luring perlu adaptasi. Peserta didik dan wali peserta didik keduanya perlu pembiasaan mengoperasikan gawai dan telepon pintar dalam pembelajaran. Orangtua harus banyak 
meluangkan waktu mendampingi anak dalam pembelajaran daring. Hal ini disebabkan peserta didik usia Madrasah Ibtidaiyah perlu bimbingan dalam pengoperasiannya. Anak juga perlu pengawasan ekstra dari orang tua. Ketika orang tua harus meluangkan waktu dalam pembelajaran daring, sebagian orang tua pserta didik dibenturkan dengan waktu karena sebagian dari mereka adalah pekerja pabrik yang tidak mungkin untuk mendampingi anak belajar di rumah. Konsekwensi lain dari pembelajaran berbasis daring di MI Miftahul Huda Jepara adalah biaya yang harus dikeluarkan untuk pengadaan gawai sebagai perangkat pembantu pembelajaran daring. Bagi sebagian orang tua wali peserta didik di MI Miftahul Huda Jepara khususnya dari kalangan bawah hal ini adalah sesuatu yang berat. Hal ini karena untuk mengakses fitur dan aplikasi untuk pembelajaran daring dibutuhkan gawai atau ponsel pintar yang harganya tidak murah. Ditambah pula mereka harus menyediakan anggaran untuk paket data supaya dapat mengakses internet.

Pembelajaran jarak jauh (berbasis daring) berbeda dengan pembelajaran jarak dekat (berbasis luring). Dalam pembelajaran daring guru lebih sulit dalam mengontrol interaksi edukatif / PBM tanpa bantuan dari orang tua. Terlebih peserta didiknya adalah pembelajar pemula (young learners). Tentunya peran serta orang tua dibutuhkan. Oleh karena itu komunikasi dan sinergi antara orangtua dan guru diperlukan mengingat kemandirian belajar anak anak berbeda dengan remaja dan orang dewasa. Anak anak butuh pendampingan penuh dari orang tua dalam pembelajaran saat belajar/sekolah dari rumah (school from home), dan berbeda dengan ketika belajar dari sekolah berbasis luring gurulah yang melakukan pendampingan penuh.

Untuk mencapai tujuan pendidikan dalam pembelajaran berbasis daring perlu dilakukan dengan membangun sinergi antara semua pihak (stake holder) terutama para guru dan orang tua. Tindakan saling melempar tanggung jawab antara guru/sekolah dengan orang tua (keluarga) tidak perlu dilakukan. Bentuk sinergi dapat dilakukan dengan menerapkan 4 unsur yakni; koordinasi, integrasi, sinkronisasi, dan simplifikasi (KISS). Pertama, koordinasi antara semua pihak pemangku kepentingan diperlukan demi keberhasilan PBM. Masing-masing pihak perlu mengerti dan melaksanakan tugas pokok dan fungsinya. Kedua, integrasi antara semua pihak pemangku kepentingan baik orang tua dan guru diperlukan. Artinya satu sama lain adalah satu sistem yang bersifat fungsional. Keberhasilan PBM berbasis daring tidak hanya upaya guru saja, ataupun 
orang tua saja tapi melibatkan semua pihak. Ketiga, sinkronisasi diperlukan guna menyelaraskan tujuan yang ingin dicapai oleh guru dan orangtua. Harapannya adalah guru dan orang tua berada pada arah yang sama. Keempat, simplifikasi dilakukan dengan menyederhanakan program menjadi usaha atau langkah kongkret. 


\section{DAFTAR PUSTAKA}

Ahmadi, Abu, and Nur Uhbiyati. Ilmu Pendidikan. Jakarta: Rineka Cipta, 2015.

Arifin. ILMU PENDIDIKAN ISLAM; Tinjauan Teoritis Dan Praktis Berdasarkan Pendekatan Interdisipliner. Jakarta: Pustaka Setia, 2014.

Basri, Hasan, and Beni Ahmad Saebani. ILMU PENDIDIKAN ISLAM. Bandung: Pustaka Setia, 2010.

Buseri, Kamrani. Dasar, Asas, Dan Prinsip Pendidikan Islam. Edited by Ahmad Juhaidi. 1st ed. Yogyakarta: Aswaja Pressindo, 2014.

Cahyati, Nika, dan Rita Kusumah, Peran Orang Tua Dalam Menerapkan Pembelajaran Di Rumah Saat Pandemi Covid 19, Jurnal Golden Age 4, no. 1 (2020).

Education, Directorate of Distance. Research Methodology. New Delhi: EXCEL BOOKS PRIVATE LIMITED, 2012.

Ernawati, Widea, Pengaruh Penggunaan Gadget Terhadap Penurunan Tajam Penglihatan Pada Anak Usia Sekolah (6-12 Tahun) Di SD Muhammadiyah 2 Pontianak Selatan, 5-6.Jurnal Keperawatan Muhammadiyah 3, no. 1, 2018.

Harahap, Ade Chita Putri, Dinda Permatasari Harahap, and Samsul Rivai Harahap. "Analisis Tingkat Stres Akademik Pada Mahasiswa Selama Pembelajaran Jarak Jauh Dimasa Covid-19." Biblio Couns: Jurnal Kajian Konseling Dan Pendidikan 3, no. $1,2020$.

Harfiyanto, Doni, Cahyo Budi Utomo, and Tjaturahono Budi, Pola Interaksi Siswa Pngguna Gadget Di SMA N 1 Semarang, Journal of Educational Social Studies 4, no. $1,2015$.

Hasbullah. Dasar-Dasar Ilmu Pendidikan. 11th ed. Jakarta: PT Raja Grafindo Persada, 2013.

Huda, Khoirul, Problematika Madrasah Dalam Meningkatkan Mutu Pendidikan Islam." Dinamika Penelitian 16, no. 2, 2016

Ilmi, Darul, Pendidikan Karakter Berbasis Nilai-Nilai Kearifan Lokal Melalui Ungkapan Bijak Minangkabau, ISLAM REALITAS: Journal of Islamic \& Social Studies 1, no. 1, 2015

Irmayanti, Yuli, Peran Orangtua Dalam Mendampingi Penggunaan Gawai Pada Anak Prasekolah, New England Journal of Medicine. Universitas Muhammadiyah Surakarta, 2018. http://www.ncbi.nlm.nih.gov/pubmed/7556065\%0Ahttp://www.pubmedcentral.nih .gov/articlerender.fcgi?artid=PMC394507\%0Ahttp://dx.doi.org/10.1016/j.humpath .2017.05.005\%0Ahttps://doi.org/10.1007/s00401-018-1825- 
z\%0Ahttp://www.ncbi.nlm.nih.gov/pubmed/27157931.

Khusniyah, Nurul Lailatul, dan Lukman Hakim, Efektivitas Pembelajaran Berbasis Daring: Sebuah Bukti Pada Pembelajaran Bahasa Inggris, Jurnal Tatsqif 17, no. 1, 19-33. doi:10.20414/jtq.v17i1.667, 2019.

Kurniawan, Machful Indra. "Tri Pusat Pendidikan Sebagai Sarana Pendidikan Karakter Anak Sekolah Dasar.” JOURNAL PEDAGOGIA 4, no. 1, 2015

—. "Tri Pusat Pendidikan Sebagai Sarana Pendidikan Karakter Anak Sekolah Dasar.” PEDAGOGIA: Jurnal Pendidikan 4, no. 1, 2015

Nadirah, Sitti, Anak Didik Perspektif Nativisme, Empirisme, Dan Konvergensi, Lentera Pendidikan: Jurnal Ilmu Tarbiyah Dan Keguruan 16, no. 2, 2013

Nata, Abuddin. Ilmu Pendidikan Islam. 2nd ed. Jakarta: Kencana, 2012.

Neuman, W Lawrence. Social Research Methods: Qualitative and Quantitative Approaches. 7th ed. United States of America: Pearson Education Limited, 2014.

- Social Research Methods: Qualitative and Quantitative Approaches. England: Pearson Education Limited, 2014.

Primayana, Kadek Hengki, and Putu Yulia Angga Dewi. "Hubungan Pola Asuh Demokratis Dan Intensitas Penggunaan Gawai Pada Anak Usia Dini." Jurnal Obsesi: Jurnal Pendidikan Anak Usia Dini 5, no. 1 (2020): 710. doi:10.31004/obsesi.v5i1.697.

Rahmatullah, Indra. "Jaminan Hak Kesehatan Pekerja Work From Office Selama Masa PSBB Covid-19.” Jurnal Buletin Hukum Dan Keadilan 4, no. 1, 2020

Ramayulis. Ilmu Pendidikan Islam. 10th ed. Jakarta: Kalam Mulia, 2013.

Sholikhah, Aas Siti. "Teori-Teori Pendidikan." Jurnal Edukasi Islami Jurnal Pendidikan Islam 7, no. 1, 2018.

Slameto. "5 Fakta Pendidikan Di Tengah Wabah Corona." Detiknews Website, 2020. https://news.detik.com/kolom/d-4969335/5- faktapendidikan-di-tengah-wabahcorona.

Sugiyono. Metode Penelitian Kuantitatif, Kualitatif Dan R\&D. 26th ed. Bandung: Alfabeta, 2017.

Syarifudin, Albitar Septian. "Impelementasi Pembelajaran Daring Untuk Meningkatkan Mutu Pendidikan Sebagai Dampak Diterapkannya Social Distancing." Jurnal Pendidikan Bahasa Dan Sastra Indonesia Metalingua 5, no. 1 (2020): 31-34. doi:10.21107/metalingua.v5i1.7072.

Tafsir, Ahmad. Ilmu Pendidikan Dalam Perspektif Islam. Edited by Tjun Surjaman. 11th ed. Bandung: PT Remaja Rosdakarya, 2014. 
Ummi, Hikmah Uswatun, and Indrya Mulyaningsih. "Journal Indonesian Language Education and Literature." Journal Indonesian Language Education and Literature 3, no. 1 (2017): 53-65. http://www.syekhnurjati.ac.id/jurnal/index.php/jeill/\%0APEMBELAJARAN.

Wardani, Kristi. "PERAN GURU DALAM PENDIDIKAN KARAKTER KI HADJAR DEWANTARA." In Proceedings of The 4th International Conference on Teacher Education; Join Conference UPI \& UPSI Bandung, Indonesia, 8-10 November 2010, 8-10. Bandung: UPI \& UPSI Bandung, 2010.

Winingsih, Endang, Peran Orang Tua Dalam Pembelajaran Jarak Jauh, Poskita.co, 2020. https://poskita.co/2020/04/02/peran-orangtua- dalampembelajaran-jarakjauh/\%0AWHO, 2020.

Yunus, Nur Rohim, and Annissa Rezki. "Kebijakan Pemberlakuan Lockdown Sebagai Antisipasi Penyebaran Corona Virus Covid-19." SALAM; Jurnal Sosial \& Budaya Syar-I 7, no, doi:10.15408/sjsbs.v7i3.15083, 2020. 